\title{
Effects of mycorrhizal inoculant, N:P supply ratio, and water depth on the growth and biomass allocation of three wetland plant species
}

\author{
Lauchlan H. Fraser and Larry M. Feinstein
}

\begin{abstract}
In the greenhouse, we investigated the growth and biomass allocation of three juvenile wetland species (Carex tribuloides Wahl., Phalaris arundinacea L., and Rumex orbiculatus Gray) under three different water depths ( $-4,0$, and $+2 \mathrm{~cm}$ relative to the soil surface), three $\mathrm{N}: \mathrm{P}$ supply ratios $(1: 30,1: 1,30: 1)$, and two mycorrhizal inoculant treatments (arbuscular mycorrhizal (AM) fungi present, absent). After 6 weeks, the plants were harvested, separated to above- and below-ground parts, oven-dried, and weighed. The mycorrhizal inoculant significantly increased plant growth and reduced root:shoot ratios. At an N:P supply ratio of 30:1, plants with AM fungi had significantly greater biomass than those plants without AM fungi. However, at 1:1 N:P supply ratio, plants without AM fungi had greater biomass. Plants without AM fungi had higher root:shoot ratios at 0 and $-4 \mathrm{~cm}$ water depth than plants with AM fungi. In general, $C$. tribuloides had the lowest growth, and unlike $P$. arundinacea and $R$. orbiculatus, was not affected by the water depth treatment. Growth of the wetland plants was limited more by nitrogen than by phosphorus. Our results suggest that at high N:P nutrient supply ratios and non-flooded conditions the growth of wetland seedlings can benefit by being inoculated with AM fungi.
\end{abstract}

Key words: Carex tribuloides, Phalaris arundinacea, Rumex orbiculatus, arbuscular mycorrhizae, wetland restoration, nitrogen:phosphorus ratio.

Résumé : Les auteurs ont étudié, en serre, la croissance et l'allocation de la biomasse chez trois espèces juvéniles de terres humides (Carex tribuloides Wahl., Phalaris arundicnacea L., et Rumex orbiculatus Gray). Les traitements étaient, la profondeur d'eau $(-4,0,+2 \mathrm{~cm})$ par rapport à la surface du sol, le ratio des apports $\mathrm{N}: \mathrm{P}(1: 30,1: 1,30: 1)$, et la présence de deux traitements d'inoculation (champignon mycorhizien arbusculaire (AM), présent ou absent). Ils ont récolté les plants après six semaines, séparé les parties épigées et hypogées, et les ont séchées au four avant de les peser. L'inoculant mycorhizien augmente significativement la croissance des plants et réduit les rapports racine:tige. Avec un ratio N:P de 30:1, les plants avec les champignons AM possèdent une plus grande biomasse que les plants non inoculés. Cependant, avec un ratio $\mathrm{N}: \mathrm{P}$ de 1:1, les plants sans mycorhize ont une plus forte biomasse. Les plants sans mycorhize AM ont des ratios racine:tige, plus élevés, à 0 et $-4 \mathrm{~cm}$ de profondeur d'eau, que les plants inoculés. En général, le $C$. tribuloides montre la croissance la plus faible, et contrairement au $P$. arundinaceae et au $R$. orbiculatus, il n'est pas affecté par la profondeur de l'eau. La croissance de ces plantes de milieux humides est plus fortement limitée par l'azote que par le phosphore. Les résultats montrent qu'avec des rapports en nutriments N:P élevés, et sous des conditions non immergées, la croissance de plantules des terres humides peut bénéficier de l'inoculation mycorhizienne.

Mots clés : Carex tribuloides, Phalaris arundinacea, Rumex orbiculatus, mycorhizes arbusculaires, restauration de terres humides, ratio azote : phosphore.

[Traduit par la Rédaction]

\section{Introduction}

Arbuscular mycorrhizal (AM) fungi are commonly found in a wide variety of host plants (Smith and Read 1997). In general, colonization by AM fungi is associated with an increase in plant growth, particularly when growth is limited by phosphorus supply (Johnson 1998; McHugh and Dighton 2004). While it has been shown that flooded soils can re-

Received 3 June 2005. Published on the NRC Research Press Web site at http://canjbot.nrc.ca on 29 October 2005.

L.H. Fraser ${ }^{1,2}$ and L.M. Feinstein. Department of Biology, University of Akron, Akron, $\mathrm{OH} 44325-3908$, USA.

${ }^{1}$ Corresponding author (e-mail: 1fraser@tru.ca).

${ }^{2}$ Present address: Department of Natural Resource Science, Thompson Rivers University, Kamloops, BC V2C 5N3, Canada. duce root and AM growth (Khan and Belik 1995; McHugh and Dighton 2004), it has also been shown that wetland and aquatic plants can be colonized by AM fungi (Khan and Belik 1995; Cooke and Lefor 1998). For example, of the 89 wetland species from 11 Connecticut freshwater wetlands sampled by Cooke and Lefor (1998), only seven species (five of which were from the family Cyperaceae) were not colonized by AM fungi.

Plant biomass allocation patterns along an environmental gradient can help to determine the ability of species to grow and compete successfully, as well as predict the relative distribution and abundance of individual species (Campbell and Grime 1989; Tilman and Wedin 1991; Figiel et al. 1995; Poorter and Nagel 2000; Güsewell et al. 2003). Experiments have demonstrated that an increase in water depth generally reduces the growth and affects morphological responses of wetland plants (Newman et al. 1996; Coops et 
Table 1. Modified Rorison's nutrient solution as applied to the N:P ratio nutrient treatments (preparation of $50 \mathrm{~mL}$; Hendry and Grime 1993).

\begin{tabular}{|c|c|c|c|c|c|}
\hline \multirow[b]{2}{*}{ Element } & \multirow[b]{2}{*}{$\mathrm{mg} \cdot 50 \mathrm{~mL}^{-1}$} & \multirow[b]{2}{*}{ Stock solutions } & \multicolumn{3}{|c|}{$\mathrm{N}: \mathrm{P}$ ratio $^{a}$} \\
\hline & & & $1: 30$ & $1: 1$ & $30: 1$ \\
\hline $\mathrm{Ca} / \mathrm{N}$ & $4.0 / 2.80$ & $\mathrm{Ca}\left(\mathrm{NO}_{3}\right)_{2} \cdot 4 \mathrm{H}_{2} \mathrm{O}$ & - & + & + \\
\hline $\mathrm{Ca} / \mathrm{N}$ & $0.1 / 0.09$ & $\mathrm{Ca}\left(\mathrm{NO}_{3}\right)_{2} \cdot 4 \mathrm{H}_{2} \mathrm{O}$ & + & - & - \\
\hline $\mathrm{Mg}$ & 1.20 & $\mathrm{MgSO}_{4} \cdot 7 \mathrm{H}_{2} \mathrm{O}$ & + & + & + \\
\hline $\mathrm{K} / \mathrm{P}$ & $7.1 / 2.80$ & $\mathrm{~K}_{2} \mathrm{HPO}_{4} \cdot 3 \mathrm{H}_{2} \mathrm{O}$ & + & + & - \\
\hline $\mathrm{K} / \mathrm{P}$ & $0.2 / 0.09$ & $\mathrm{~K}_{2} \mathrm{HPO}_{4} \cdot 3 \mathrm{H}_{2} \mathrm{O}$ & - & - & + \\
\hline $\mathrm{Fe}$ & 0.15 & Fe EDTA & + & + & + \\
\hline $\mathrm{Mn}$ & 0.03 & $\mathrm{MnSO}_{4} \cdot 4 \mathrm{H}_{2} \mathrm{O}$ & + & + & + \\
\hline B & 0.03 & $\mathrm{H}_{3} \mathrm{BO}_{3}$ & + & + & + \\
\hline Mo & 0.005 & $\left(\mathrm{NH}_{4}\right)_{6} \mathrm{Mo}_{7} \mathrm{O}_{24} \cdot 4 \mathrm{H}_{2} \mathrm{O}$ & + & + & + \\
\hline $\mathrm{Zn}$ & 0.005 & $\mathrm{ZnSO}_{4} \cdot 7 \mathrm{H}_{2} \mathrm{O}$ & + & + & + \\
\hline $\mathrm{Cu}$ & 0.005 & $\mathrm{CuSO}_{4} \cdot 5 \mathrm{H}_{2} \mathrm{O}$ & + & + & + \\
\hline $\mathrm{K}$ & 3.405 & $\mathrm{~K}_{2} \mathrm{SO}_{4}\left(0.5 \mathrm{~mol} \cdot \mathrm{L}^{-1}\right)$ & - & - & + \\
\hline $\mathrm{Ca}$ & 27.07 & $\mathrm{CaCl}_{2} \cdot 6 \mathrm{H}_{2} \mathrm{O}$ & + & - & - \\
\hline
\end{tabular}

al. 1996; Lentz and Dunson 1998; Lenssen et al. 1999; Miller and Zedler 2003; Fraser and Karnezis 2005). For example, a decrease in root:shoot ratios has been shown with increasing depth in water level (Figiel et al. 1995; Coops et al. 1996; Edwards et al. 2003). Nutrient supply also affects growth responses, plants not only grow at a slower rate at low nutrient supply compared with high nutrient supply, but they also increase their biomass allocation to roots (Poorter and Nagel 2000). However, little is known about the interacting effects of water depth, nutrient supply ratios, and, in particular, mycorrhizal colonization on total plant biomass and biomass allocation patterns of wetland plants (see Stevens et al. 2002).

We tested the growth and biomass allocation of three wetland perennial plant species (Carex tribuloides Wahl., Phalaris arundinacea L., and Rumex orbiculatus Gray) in a 3 $($ species $) \times 3(\mathrm{~N}: \mathrm{P}$ supply ratios $) \times 3$ (water levels $) \times 2$ (mycorrhizal) experimental design located in a climate-controlled greenhouse. The three main questions we address are the following: (1) Does the presence of AM fungi affect the growth and biomass allocation of the three wetland species tested? (2) Are there interacting effects between the AM fungi treatment and different $\mathrm{N}: \mathrm{P}$ supply ratios in the growth and biomass allocation of wetland plants? (3) Are there interacting effects between AM fungi treatment and water depth in the growth and biomass allocation of wetland plants? In addition to these three main questions, we were also able to ask whether water depth, different nitrogen:phosphorus ratios, and the interaction between these two factors affected plant growth and biomass allocation. Two-week-old seedlings were used because it is already well established that flooding is a constraint to germination (van der Valk 1981; Keddy and Ellis 1985; Casanova and Brock 2000; Jensen 2004), but the gap in the literature regards the growth and biomass allocation of wetland seedlings to the interacting effects of mycorrhizal fungi infection, $\mathrm{N}: \mathrm{P}$ nutrient supply ratios, and water depth.

\section{Methods}

A common wet meadow sedge, $C$. tribuloides, a wetland forb, $R$. orbiculatus, and an invasive wet meadow grass, $P$. arundinacea, were grown in a factorial experiment with four treatments: 3 plant species $\times 3$ water depths $(+2,0$, and $-4 \mathrm{~cm}$ relative to soil level) $\times 3 \mathrm{~N}: \mathrm{P}$ ratios $(30: 1,1: 1$, and 1:30) $\times 2$ mycorrhizal treatments (with or without an AM fungal inoculant), replicated three times for a total of 162 individual potted plants. A randomized block design was used.

We selected $C$. tribuloides, $P$. arundinacea, and $R$. orbiculatus because they occur together in wet meadow communities in the American Midwest and are all rhizomatous perennials. Carex tribuloides, bristleback sedge, has culms ranging from 3-9 mm wide and $60-90 \mathrm{~cm}$ tall. Short lateral rhizomes, and rapid growth of the culms often cause the formation of a robust tussock (Crow and Hellquist 2000). Cooke and Lefor (1998) measured a 50\% mycorrhizal colonization for $C$. tribuloides. Phalaris arundinacea, reed canary grass, has culms ranging from $60-150 \mathrm{~cm}$ tall (Hitchcock 1950). This fast-growing grass is considered an invasive plant species. Mycorrhizal colonization for $P$. arundinacea has been shown to vary from $34 \%$ to $80 \%$ (Wetzel and van der Valk 1998; Cooke and Lefor 1998). Rumex orbiculatus, great water dock, is a forb ranging in height from 80 to $200 \mathrm{~cm}$, with flat, elongate leaves that can reach $60 \mathrm{~cm}$ in length (Crow and Hellquist 2000). We could find no accounts of mycorrhizal colonization for $R$. orbiculatus, but $R$. altissimus had colonization between $10 \%$ and $20 \%$ (Cooke and Lefor 1998).

Seeds were germinated on filter paper in Petri dishes and seedlings were transplanted to $473-\mathrm{mL}$ pots (diameter of $8.9 \mathrm{~cm})$ filled with autoclaved sand $(11.4 \mathrm{~cm}$ depth). We used sand, as opposed to a potting soil, to better control nutrient supply ratios (Wetzel and van der Valk 1998; Güsewell et al. 2003; McHugh and Dighton 2004). We sterilized the sand in a steam autoclave ( $9 \mathrm{~kg}$ bag for $3 \mathrm{~h}$ ) to kill any live fungal spores. For the pots that received the AM fungal inoculum, we removed the top $3 \mathrm{~cm}$ of sand for each cup, mixed in $2.5 \mathrm{~cm}^{3}$ of a commercially supplied AM fungal inoculant (Root Boost Mycorrhizal Inoculant ${ }^{\circledR}$, Gardens Alive, Lawrenceburg, Indiana; includes mycorrhizal spores 
Table 2. Percent mycorrhizal colonization by species, water level, and N:P ratio for plants grown in the mycorrhizal inoculant treatment.

\begin{tabular}{lcccl}
\hline $\begin{array}{l}\text { Water level } \\
(\mathrm{cm})\end{array}$ & $\mathrm{N}: \mathrm{P}$ ratio & $\begin{array}{l}\text { Carex tribuloides } \\
\text { (\% colonization) }\end{array}$ & $\begin{array}{l}\text { Phalaris arundinacea } \\
\text { (\% colonization) }\end{array}$ & $\begin{array}{l}\text { Rumex orbiculatus } \\
\text { (\% colonization) }\end{array}$ \\
\hline-4 & $30: 1$ & 8.33 & 13.70 & 22.69 \\
-4 & $1: 1$ & 8.08 & 4.41 & 27.66 \\
-4 & $1: 30$ & 7.69 & 11.28 & 16.13 \\
0 & $30: 1$ & 12.90 & 7.80 & 9.30 \\
0 & $1: 1$ & 4.50 & 6.67 & 8.50 \\
0 & $1: 30$ & 10.45 & 26.15 & 7.69 \\
+2 & $30: 1$ & 1.00 & 11.10 & NA \\
+2 & $1: 1$ & 4.40 & 49.02 & NA \\
+2 & $1: 30$ & 4.10 & 25.55 & NA \\
& & $6.83(1.22)$ & $17.30(4.73)$ & $15.33(3.41)$ \\
\hline
\end{tabular}

Note: Mean percent colonization by species are presented at the bottom of each species column with \pm 1 $\mathrm{SE}$ in parentheses. NA, not available.

of Glomus spp. and Gigaspora spp.) and reapplied the sand - AM-inoculant mixture as a top layer in the pots.

The commercial inoculant and the sterilized sand were analyzed for nitrate nitrogen, total nitrogen, and available phosphorus. Nitrate $\mathrm{N}$ was determined on an autoanalyzer using the copper-cadmium method (Technicon Industrial Systems 1978). Total $\mathrm{N}$ was determined using the Dumas automated combustion technique (McGill and Fiqueiredo 1993) using a CNS analyzer (Carla Erba, Milan, Italy). Available phosphorus (ortho-P) was extracted using a 1:25 ratio of $1 \mathrm{~g}$ of sample and $25 \mathrm{~mL}$ of Kelowna extract (Van Lierop 1988) after shaking at low speed for $1 \mathrm{~h}$. Available $\mathrm{P}$ was analyzed on the autoanalyzer using the ascorbic acid method (Technicon Industrial Systems 1974).

The $473 \mathrm{~mL}$ sand-filled pots had holes in the bottom for water uptake and a filter paper under the sand to prevent loss of sand. Each of the sand-filled pots was placed within an outer $946 \mathrm{~mL}$ pot that had holes drilled at the appropriate level relative to the soil surface (either $-4,0$, or $+2 \mathrm{~cm}$; see Fraser and Karnezis 2005).

We waited for the development of primary leaves, which was $14 \mathrm{~d}$, before initiating the water depth and nutrient treatments. The three different $\mathrm{N}: \mathrm{P}$ ratio nutrient solutions were made by modifying Rorison nutrient solution (Hendry and Grime 1993; Table 1). Every fourth day, $50 \mathrm{~mL}$ of the appropriate nutrient solution was applied to each pot: $30: 1$, $2.80 \mathrm{mg} \mathrm{N}$ and $0.09 \mathrm{mg} \mathrm{P} ; 1: 1,2.80 \mathrm{mg} \mathrm{N}$ and $2.80 \mathrm{mg} \mathrm{P}$; $1: 30,0.09 \mathrm{mg} \mathrm{N}$ and $2.80 \mathrm{mg} \mathrm{P}$ (relative amount of nutrients per $50 \mathrm{~mL}$ solution). The $30: 1$ and $1: 1 \mathrm{~N}: \mathrm{P}$ nutrient supply ratios are commonly used experimental combinations (Güsewell et al. 2003; Güsewell 2005). The 1:30 N:P ratio is less commonly used in experimental designs and is also uncommon in natural conditions; however, we chose to compare these extreme nitrogen and phosphorus limitations as treatment variables as a first step to understanding the interactions among mycorrhizal inoculation, N:P supply ratio, and water depth on biomass accumulation and root:shoot ratio.

To better isolate the effects of the water depth treatment on the three species, other abiotic factors were standardized. A daily, 16-h photoperiod was provided by four, $1000 \mathrm{~W}$, High Pressure Sodium bulbs providing an average photosynthetically active radiation (measured with a LiCor LI-250 light meter) of $150.5 \mu \mathrm{mol} \cdot \mathrm{s}^{-1} \cdot \mathrm{m}^{-2}( \pm 8.2 \mathrm{SD})$ on the exper- imental plants. Windows in the room were covered to prevent incident solar radiation. Temperature ranged between 20 and $24{ }^{\circ} \mathrm{C}$ and was maintained by air-conditioner units. Humidity ranged between $40 \%$ and $50 \%$ and was self-maintained because of the evaporation of the water from all the microcosms. After the initial 2 weeks of germination, plants were watered every other day. A watering wand was used to apply distilled water to the outer sleeve of each individual microcosm. Algae grew in some of the flooded microcosms but were physically removed immediately so that algae were never present longer than $24 \mathrm{~h}$.

Plants were harvested after 8 weeks of growth (6 weeks in experimental treatment conditions). Each plant's biomass was divided into above-ground and below-ground biomass, placed in a drying oven for $48 \mathrm{~h}$ at $80{ }^{\circ} \mathrm{C}$, and weighed to the nearest ten-thousandth gram. Plants that died during the experiment were removed at time of death and weighed.

We randomly selected one of the three replicates that had been treated with the mycorrhizal inoculant (for a total of 27 plants: 3 species $\times 3$ water depths $\times 3 \mathrm{~N}$ :P supply ratios) to measure mycorrhizal colonization. We also randomly selected one of each of the three wetland species that were not inoculated with AM fungi for a measurement of mycorrhizal colonization to ensure the sterility of the autoclaved sand. Ten $1-\mathrm{cm}$ pieces of fine roots were cut from each of the 30 plants and stained in $0.05 \%$ trypan blue in lactophenol following the methodology of Norris et al. (1994). Stained roots were mounted on slides in lactophenol, and colonization was estimated at $\times 100$ magnification using the cross-hair method (McGonigle et al. 1990), with a minimum of 100 observations per slide, categorizing colonization by vesicle, arbuscule, both vesicle and arbuscule, hyphae, or absence of fungal tissue.

Three one-way ANOVAs were done to test the effect of species, N:P ratio, and water depth on percent mycorrhizal colonization. A general linear model was applied to measure for block effects by treatment variables on total biomass and root:shoot ratios. No block effects were detected, so we proceeded by conducting four-way fixed-effects ANOVAs for the combined AM fungi by species by water depth by $N: P$ ratio nutrient addition effect on total biomass and root:shoot ratio. Tukey's HSD test was run to determine statistical significance between means. Logarithmic transformations were 
Table 3. Results from two 4-way ANOVAs for dry biomass (mg) (log) and root:shoot ratio (log), with species, N:P ratio, water level, and mycorrhizas as the independent factors.

\begin{tabular}{|c|c|c|c|c|c|}
\hline \multirow[b]{2}{*}{ Source } & \multirow[b]{2}{*}{$\mathrm{df}$} & \multicolumn{2}{|c|}{ Log biomass } & \multicolumn{2}{|c|}{ Log root:shoot } \\
\hline & & $F$ ratio & $p$ & $F$ ratio & $p$ \\
\hline Species & 2 & 21.757 & $<0.001$ & 4.441 & 0.014 \\
\hline NP & 2 & 45.981 & $<0.001$ & 10.041 & $<0.001$ \\
\hline Water & 2 & 69.074 & $<0.001$ & 5.332 & 0.006 \\
\hline Myc & 1 & 4.359 & 0.039 & 24.156 & $<0.001$ \\
\hline Species $\times \mathrm{NP}$ & 4 & 5.972 & $<0.001$ & 3.046 & 0.020 \\
\hline Species $\times$ water & 4 & 39.517 & $<0.001$ & 1.050 & 0.385 \\
\hline Species $\times$ myc & 2 & 1.063 & 0.349 & 0.301 & 0.741 \\
\hline $\mathrm{NP} \times$ water & 4 & 27.977 & $<0.001$ & 6.148 & $<0.001$ \\
\hline $\mathrm{NP} \times$ myc & 2 & 32.647 & $<0.001$ & 1.733 & 0.182 \\
\hline Water $\times$ myc & 2 & 0.362 & 0.697 & 3.641 & 0.029 \\
\hline Species $\times \mathrm{NP} \times$ water & 8 & 4.216 & $<0.001$ & 1.434 & 0.190 \\
\hline Species $\times \mathrm{NP} \times$ myc & 4 & 2.198 & 0.074 & 2.362 & 0.058 \\
\hline Species $\times$ water $\times$ myc & 4 & 0.376 & 0.825 & 0.492 & 0.741 \\
\hline $\mathrm{NP} \times$ water $\times$ myc & 4 & 13.291 & $<0.001$ & 1.337 & 0.261 \\
\hline Species $\times \mathrm{NP} \times$ water $\times$ myc & 8 & 1.989 & 0.055 & 1.613 & 0.129 \\
\hline Error & 108 & & & & \\
\hline
\end{tabular}

Note: Error mean squares were 0.507 for log biomass and 0.021 for log root:shoot.

done on the biomass and root:shoot ratio data to improve homoscedasticity and normality of residuals. The general linear model, all ANOVAs and the post-hoc analyses were conducted using Systat 8 (SPSS 1998).

\section{Results}

Mycorrhizal colonization was observed in all the species and in all of the experimental treatments, with the exception of $R$. orbiculatus in flooded conditions $(+2 \mathrm{~cm})$ because of one hundred percent mortality resulting in insufficient roots for staining (Table 2). None of the ANOVAs to test mean differences in percent mycorrhizal colonization were significant $(p<0.05)$; however, the effect of species on percent colonization was significant at a $p<0.10(F=2.752$; $p=$ 0.087; Table 2). Carex tribuloides had the lowest percent colonization. Mycorrhizal colonization was not found in the three plants randomly sampled from those plants grown without mycorrhizal inoculant.

The soil chemical analysis showed that the inoculant had 6 ppm $\mathrm{NO}_{3}, 0.03 \%$ total $\mathrm{N}$, and 5 ppm available P. Therefore, by volume, the inoculant contained $0.015 \mathrm{mg} \mathrm{NO}$ and $0.013 \mathrm{mg}$ available $\mathrm{P}$, which were very low levels and unlikely to cause indirect nutrient addition effects especially considering the rate of nutrient solution applied as treatment. The autoclaved sand had $4 \mathrm{ppm} \mathrm{NO}_{3}, 0.01 \%$ total $\mathrm{N}$, and 1 ppm available $\mathrm{P}$.

The two four-way fixed-effect ANOVAs showed that dry biomass and root:shoot ratio were significantly affected $(p<0.05)$ by AM fungi, species, $\mathrm{N}: \mathrm{P}$ ratio, and water depth (Table 3). The biomass of plants grown in the presence of AM fungi was significantly greater than those plants grown without AM fungi (Fig. 1a). Root:shoot ratio in the presence of mycorrhizal fungi was significantly lower than the mycorrhizal absent treatment (Fig. 1a). Carex tribuloides had a significantly lower dry biomass and root:shoot ratio than $P$. arundinacea and $R$. orbiculatus (Fig. $1 b$ ). The $\mathrm{N}: \mathrm{P}$ ratio with the lowest biomass was 1:30, and the 1:1 N:P ratio had the greatest biomass (Fig. 1c). The N:P nutrient supply ratio of 1:1 had the lowest root:shoot ratios compared with 1:30 and 30:1 (Fig. 1c). The lowest biomass was found in the flooded $(+2 \mathrm{~cm})$ water level treatment, which was significantly lower than the biomass at 0 and $-4 \mathrm{~cm}$ water depths (Fig. 1d). The lowest root:shoot ratios were found in the elevated $(-4 \mathrm{~cm})$ water level treatment (Fig. 1d).

The significant two-way interaction effects on dry biomass shown by the four-way fixed-effect ANOVA were $\mathrm{N}: \mathrm{P}$ ratio $\times \mathrm{AM}$ fungi; species $\times \mathrm{N}: \mathrm{P}$; species $\times$ water depth; and, N:P $\times$ water depth (Table 3 ). Dry biomass was significantly greater when the mycorrhizal innoculant was present at the 30:1 N:P ratio compared with the mycorrhizal absent treatment (Fig. 2a). However, biomass was greater in the AM fungi absent treatment at the $1: 1 \mathrm{~N}: \mathrm{P}$ ratio compared with the AM fungi present treatment. There was no significant interaction effect on biomass between water depth and AM fungi (Fig. 2b). $R$. orbiculatus and $P$. arundinacea biomass responded similarly to $\mathrm{N}: \mathrm{P}$ nutrient supply ratio, with maximum biomass at the $1: 1$ ratio and minimum biomass at the 1:30; whereas $C$. tribuloides biomass showed no response to $\mathrm{N}: \mathrm{P}$ ratios (Fig. 2c). Carex tribuloides also showed no growth response to water depth (Fig. 2d), but $P$. arundinacea and $R$. orbiculatus had greater biomass at 0 and $-4 \mathrm{~cm}$ water depth. Figure $2 e$, the $\mathrm{N}: \mathrm{P} \times$ water depth interaction, demonstrated that the dry biomass at 1:30 N:P ratio was not affected by the depth of the water level, whereas biomass at $+2 \mathrm{~cm}$ water depth was significantly less at $\mathrm{N}: \mathrm{P}$ ratios of $1: 1$ and $30: 1$ compared with water depths at 0 and $-4 \mathrm{~cm}$.

The significant two-way interaction effects on root:shoot ratios shown by the four-way fixed-effect ANOVA were the following: water depth $\times$ AM fungi, species $\times \mathrm{N}: \mathrm{P}$ ratio, 
Fig. 1. Mean dry biomass and root:shoot ratio of plants separated by treatment: AM fungi $(a)$, species $(b)$, N:P ratio $(c)$, and water depth (d). Error bars represent \pm 1 SE. The species are Carex tribuloides, Phalaris arundinacea, and Rumex orbiculatus. N:P ratios are 1:30, 1:1, and 30:1. Water depths are $+2,0$, and $-4 \mathrm{~cm}$ relative to soil level. AM fungi are either absent or present. Bars in figures sharing the same letter are not significantly different using Tukey's HSD.

a)

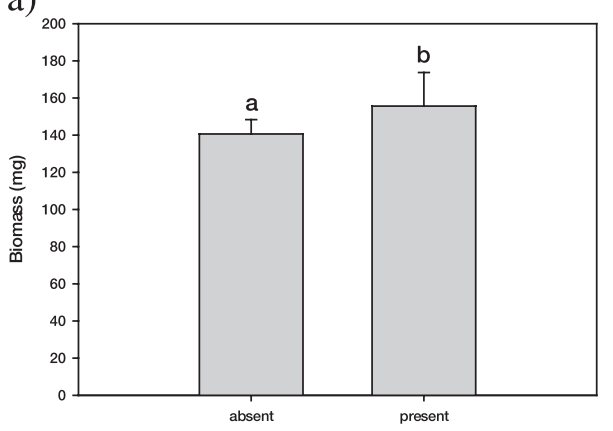

b)

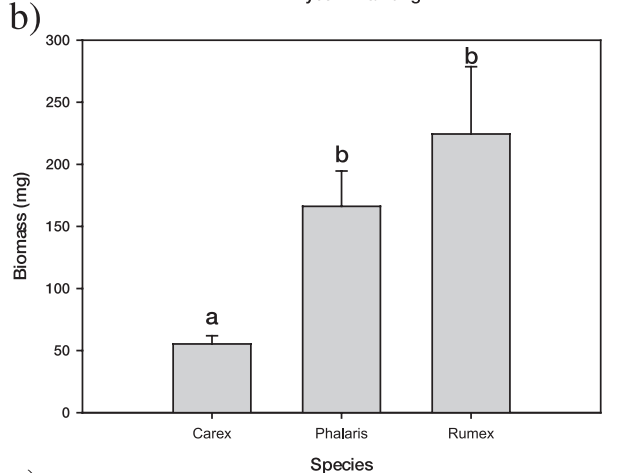

c)

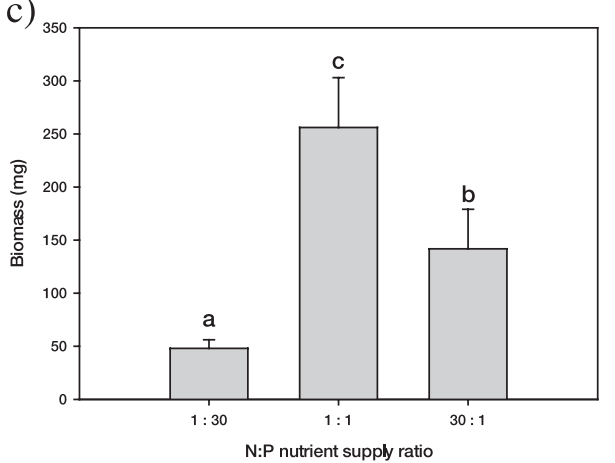

d)

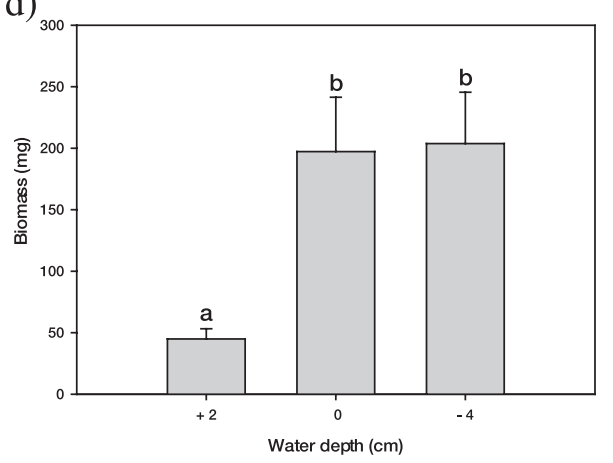

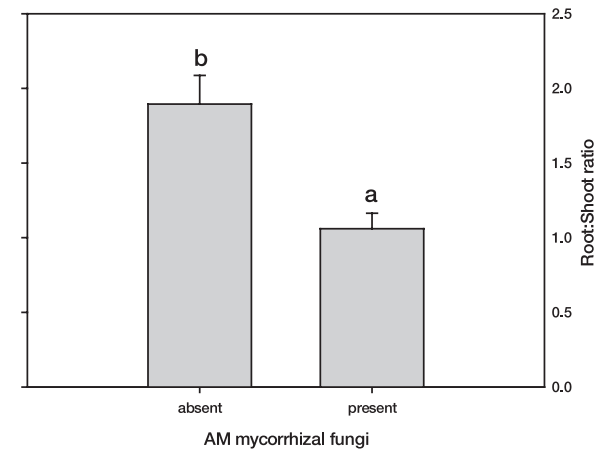
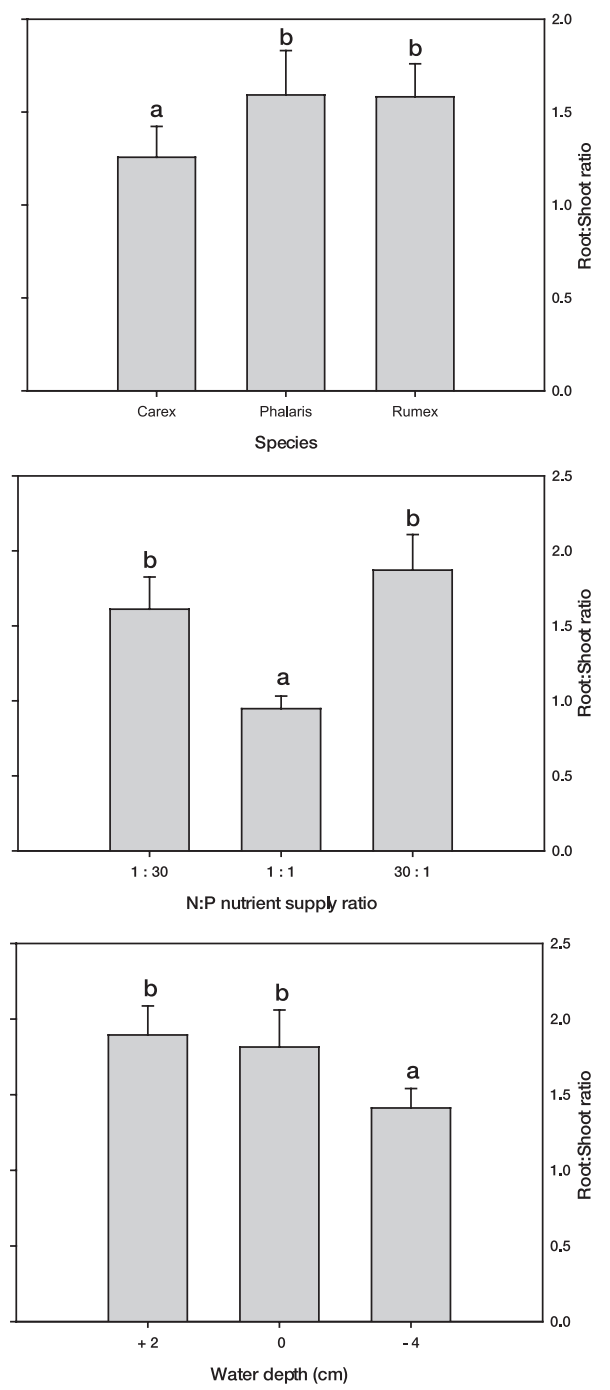

cantly lower in the N:P supply ratio treatment of $1: 30$ compared with treatment of 1:1 and 30:1 (Fig. 2c). The lowest root:shoot ratio for $P$. arundinacea was at $1: 1 \mathrm{~N}: \mathrm{P}$ ratio, and R. orbiculatus showed no significant difference in root:shoot ratio across the $\mathrm{N}: \mathrm{P}$ supply ratios (Fig. $2 c$ ). The $\mathrm{N}: \mathrm{P} \times$ water depth interaction showed that the root:shoot ratio under the 1:30 and 1:1 N:P ratio was lowest at $+2 \mathrm{~cm}$ 
Fig. 2. Mean dry biomass and root:shoot ratio of plants separated by two-way treatment interactions of $\mathrm{N}: \mathrm{P}$ ratio $\times$ AM fungi $(a)$, water depth $\times$ AM fungi $(b)$, species $\times \mathrm{N}: \mathrm{P}$ ratio $(c)$, species $\times$ water depth $(d)$, and N:P ratio $\times$ water level $(e)$. The species are Carex tribuloides, Phalaris arundinacea, and Rumex orbiculatus. N:P ratios are 1:30, 1:1, and 30:1. Water depths are $+2,0$, and $-4 \mathrm{~cm}$ relative to soil level. AM fungi are either absent or present.

water depth, while there was no significant effect on root:shoot ratios at 30:1 N:P supply ratio (Fig. 2e). There were no significant two-way interactions on root:shoot ratios between $\mathrm{N}: \mathrm{P}$ ratio $\times$ AM fungi (Fig. 2a) and species $\times$ water depth (Fig. 2d).

\section{Discussion}

Our primary objective was to test the effects of the mycorrhizal inoculant on 8-week-old wetland plant growth and biomass allocation by plant species, water level, and N:P supply ratios. Our examination of percent mycorrhizal colonization was to ensure that the inoculant was effective, and that the non-mycorrhizal treatment plants were indeed free from colonization by AM fungi, which seemed to be satisfied on both counts.

Our first question was whether the AM fungi affected growth and biomass allocation of the wetland plants. We found that the total dry biomass of the three wetland plants combined (C. tribuloides, $P$. arundincacea, and $R$. orbiculatus) was greater in the presence of AM fungi, and that root:shoot ratios were reduced nearly by half in the presence of AM fungi. These results are concordant with other studies investigating the mycorrhizal effects on plant growth (Oliver et al. 1983; McHugh and Dighton 2004; see also Smith and Read 1997 for review). The low root:shoot ratio we found in the presence of AM fungi is a typical response of terrestrial plants (Smith and Read 1997), and has also been documented in two salt marsh grasses (McHugh and Dighton 2004). However, in some cases the growth of juvenile plants has been shown to be negatively associated with mycorrhizal inoculation owing to the carbon demand of the fungi (Smith et al. 1979). Indeed, the dependency of a mycorrhizal association may vary not only by plant species but with the stage of growth of the plant, and can therefore potentially influence plant establishment and the responsiveness of the plant to mycorrhizal colonization (Allsopp and Stock 1992).

Our second question addressed whether there was an interacting effect of AM fungi and N:P supply ratios on growth and biomass allocation. The interaction between the mycorrhizal treatment and $\mathrm{N}: \mathrm{P}$ supply ratio was significant for total dry biomass, but not the root:shoot ratio. Plants grown at 30:1 N:P ratio had significantly greater biomass when grown in the treatment containing the mycorrhizal inoculant. Plants exposed to AM fungi in our study seemed to be more efficient at using very low levels of phosphorus than plants without AM fungi, which was also demonstrated by Oliver et al. (1983), Dhillion (1992), and McHugh and Dighton (2004). White and Charvat (1999), though, found that mycorrhizal colonization of Lythrum salicaria (a fastgrowing wetland plant) had no effect on total biomass under low phosphorus supply. Stevens et al. (2002) found increased AM colonization of L. salicaria under low phosphorus supply $(<5 \mathrm{mg} / \mathrm{L})$, but the presence of AM fungi did not affect plant performance. The apparent cost to mycorrhizal infection was demonstrated in our experiment within the 1:1 $\mathrm{N}: \mathrm{P}$ ratio treatment, with greater biomass found in plants without AM fungi.

It is well documented that wetland plant seedlings have reduced growth and survivorship under flooded conditions (Casanova and Brock 2000; Edwards et al. 2003; Fraser and Karnezis 2005). Our third question was whether there was a significant interaction between the mycorrhizal inoculant and water depth on biomass and root:shoot ratios. Our results showed no such affect on biomass. Root:shoot ratios were affected such that the allocation of biomass to roots was greater in the absence of AM fungi at 0 and $-4 \mathrm{~cm}$ water depths compared with $+2 \mathrm{~cm}$. We suggest that such a change in biomass allocation may affect long-term biomass accumulation, survivorship, and competitive ability. For example, plants with AM fungi that allocate more resources to above-ground growth may exhibit a greater ability to maintain photosynthesis and a greater competitive advantage for light.

There was no difference in biomass or root:shoot ratios between the presence and absence of AM fungi under flooded conditions. Therefore, mycorrhizal inoculation of the three seedling species under flooded conditions did not affect the growth parameters tested. However, our experiment was not designed to tell us whether seedlings inoculated with mycorrhiza under elevated conditions $(-4 \mathrm{~cm})$ are then more or less resistant to a flooding treatment. Hydrologic regimes in natural wetlands are highly variable; therefore, it would be interesting to test whether plants colonized by mycorrhizal fungi under non-flooded conditions are then more resistant to flooding. Mycorrhizal colonization has been shown to alter water relations of terrestrial plants (Fitter 1988; Koide 1993). Perhaps wetland plant water relations are also affected by mycorrhizas resulting in an increased tolerance of flooded conditions; that is, through (1) increases in transpiration rates and stomatal conductance (Fitter 1988; Koide 1993), and (2) increased root aeration due to increased photosynthesis from a greater allocation to above-ground growth.

There was no difference in total biomass or root:shoot ratios between plant species with regard to mycorrhizal treatment, which suggests that $C$. tribuloides, $P$. arundinacea, and $R$. orbiculatus respond similarly in terms of growth and biomass allocation to mycorrhizal inoculation. Before 1987, it was generally thought that the sedge family was non-mycorrhizal, but studies since have proven otherwise (see Muthukumar et al. 2004 for review). The sedge in our study (C. tribuloides) was mycorrhizal and performed similarly, with respect to the mycorrhizal inoculant treatment, to the other species. There is no evidence from our study to suggest that $P$. arundinacea, the fast-growing invasive, had a comparatively greater growth benefit accruing from the mycorrhizal inoculation than $C$. tribuloides and $R$. orbiculatus. 

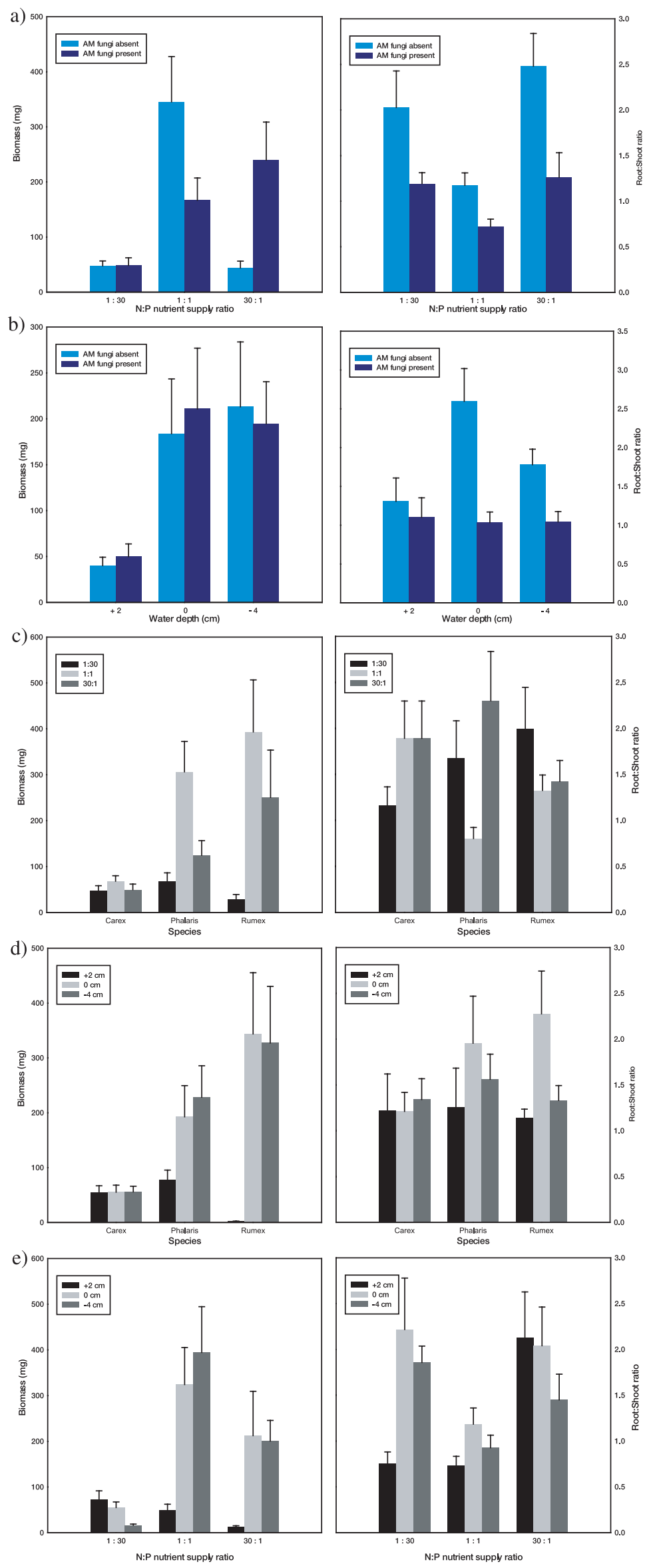
Pairwise competition experiments under similar experimental conditions involving mycorrhizal inoculation would be needed to better characterize species-level effects due to AM fungi colonization.

We found that the effects of water level and N:P supply ratio on the growth and biomass allocation of the three wetland plants tested generally confers with other studies. Flooding has been shown to cause a reduction in growth and a reduction in the allocation to root tissue resulting in reduced root:shoot ratios for these same wetland species (Fraser and Karnezis 2005). The exception in our study was C. tribuloides, which showed no response in growth or root:shoot ratio to water level. However, this may be explained by the slower growth rate of $C$. tribuloides in combination with the short time-length of the experiment (only eight weeks). Fraser and Karnezis (2005) grew C. tribuloides, $P$. arundinacea, and $R$. orbiculatus over a six-month period.

Nitrogen seemed to limit growth to a greater degree than phosphorus. Despite the 30-fold greater phosphorus supply, plants in the 1:1 treatments produced only a twofold biomass compared with the 30:1 treatment. This suggests that plants were able to utilize low levels of phosphorus, or that the phosphorus levels at the N:P 1:1 treatment was excessive. Other studies that manipulated N:P supply ratios also found that biomass increased with an increase in the $\mathrm{N}: \mathrm{P}$ supply ratio up to 45:1 (Güsewell et al. 2003). Root:shoot ratios were also significantly greater when $\mathrm{N}: \mathrm{P}$ supply ratios were at 1:30, demonstrating an increase in root allocation under limited nutrient conditions (Poorter and Nagel 2000).

Only limited statistical analyses could be conducted on the percent mycorrhizal colonization data, but the percent mycorrhizal colonization of $C$. tribuloides was generally less than the other two plants. Although this difference was significant at $p<0.10$ it did not seem to have an effect on plant growth and biomass allocation as evidenced by the data discussed above. However, more research is needed to determine whether there is a correlation between percent colonization and plant growth performance.

\section{Acknowledgements}

We thank Traci Branch who autoclaved the sand. Two Akron City Public school teachers, Morgan Greene and Stacy Beck-Ross, helped prepare and run the experiment. Comments from two anonymous reviewers improved the manuscript. Funding was provided by the National Science Foundation (GK-12 grant No. 0086378).

\section{References}

Allsopp, N., and Stock, W.D. 1992. Density dependent interactions between VA mycorrhizal fungi and even-aged seedlings of two perennial Fabaceae species. Oecologia, 91: 281-287. doi: 10. 1007/BF00317797.

Campbell, B.D., and Grime, J.P. 1989. A comparative study of plant responsiveness to the duration of episodes of mineral nutrient enrichment. New Phytol. 112: 261-267.

Casanova, M.T., and Brock, M.A. 2000. How do depth, duration and frequency of flooding influence the establishment of wetland plant communities? Plant Ecol. 147: 237-250. doi: 10. 1023/A:1009875226637.

Cooke, J.C., and Lefor, M.W. 1998. The mycorrhizal status of selected plant species from Connecticut wetlands and transition zones. Restor. Ecol. 6: 214-222. doi: 10.1111/j.1526-100X. 1998.00628.x.

Coops, H., van den Brink, F.W.B., and van der Velde, G. 1996. Growth and morphological responses of four helophyte species in an experimental water-depth gradient. Aquat. Bot. 54: 11-24. doi: 10.1016/0304-3770(96)01025-X.

Crow, G.E., and Hellquist, C.B. 2000. Aquatic and wetland plants of Northeastern North America, a revised and enlarged edition of Norman C. Fassett's a manual of aquatic plants, Volumes 1 and 2. University of Wisconsin Press, Madison, Wisc.

Dhillion, S.S. 1992. Host-endophyte specificity of vesicular-arbuscular mycorrhizal colonization of Oryza sativa L. at the pretransplant stage in low or high phosphorus soil. Soil Biol. Biochem. 24: 405-412. doi: 10.1016/0038-0717(92)90202-9.

Edwards, A.L., Lee, D.W., and Richards, J.H. 2003. Responses to a fluctuating environment: effects of water depth on growth and biomass allocation in Eleocharis cellulosa Torr. (Cyperaceae). Can. J. Bot. 81: 964-975. doi: 10.1139/b03-091.

Figiel, C.R., Collins, B., and Wein, G. 1995. Variation in survival and biomass of two wetland grasses at different nutrient and water levels over a six week period. Bull. Torrey Bot. Club, 122: 24-29.

Fitter, A.H. 1988. Water relations of red clover, Trifolium pretense L., as affected by VA mycorrhizal infection and phosphorus supply before and during drought. J. Exp. Bot. 39: 595-604.

Fraser, L.H., and Karnezis, J.P. 2005. A comparative assessment of seedling survival and biomass accumulation for fourteen wetland plant species grown under minor water-depth differences. Wetlands, 25. In press.

Güsewell, S. 2005. High nitrogen:phosphorus ratios reduce nutrient retention and second-year growth of wetland sedges. New Phytol. 166: 537-550. doi: 10.1111/j.1469-8137.2005.01320.x. PMID: 15819916.

Güsewell, S., Bollens, U., Ryser, P., and Klötzli, F. 2003. Contrasting effects of nitrogen, phosphorus and water regime on firstand second-year growth of 16 wetland plant species. Funct. Ecol. 17: 754-765. doi: 10.1111/j.1365-2435.2003.00784.x.

Hendry, G.A.F., and Grime, J.P. 1993. Methods in comparative plant ecology: a laboratory manual. Chapman and Hall, London, UK.

Hitchcock, A.S. 1950. Manual of the grasses of the United States, 2nd ed. USDA Misc. Publ. No. 200. US Government Printing Office, Washington, D.C.

Jensen, K. 2004. Dormancy patterns, germination ecology, and seed-bank types of twenty temperate fen grassland species. Wetlands, 24: 152-166.

Johnson, N.C. 1998. Responses of Salsola kali and Panicum virgatum to mycorrhizal fungi, phosphorus and soil organic matter: implications for reclamation. J. Appl. Ecol. 35: 86-94. doi: 10. 1046/j.1365-2664.1998.00277.x.

Keddy, P.A., and Ellis, T.H. 1985. Seedling recruitment of 11 wetland plant species along a water level gradient: shared or distinct responses? Can. J. Bot. 63: 1876-1879.

Khan, A.G., and Belik, M. 1995. Occurrence and ecological significance of mycorrhizal symbiosis in aquatic plants. In Mycorrhiza: structure, function, molecular biology and biotechnology. Edited by A. Varma and B. Hock. SpringerVerlag, Berlin, Germany. pp. 627-666.

Koide, R. 1993. Physiology of the mycorrhizal plant. Adv. Plant Pathol. 9: 33-54.

Lenssen, J.P.M., Menting, F.B.J., van der Putten, W.H., and Blom, C.W.P.M. 1999. Effects of sediment type and water level on biomass production of wetland plant species. Aquat. Bot. 64: 151-165. doi: 10.1016/S0304-3770(99)00012-1.

Lentz, K.A., and Dunson, W.A. 1998. Water level affects growth 
of endangered northeastern bulrush, Scirpus ancistrochaetus Schuyler. Aquat. Bot. 60: 213-219. doi: 10.1016/ S0304-3770(97)00098-3.

McGill, W.B., and Fiqueiredo, C.T. 1993. Total nitrogen. In Soil sampling and methods of analysis. Edited by M.R. Carter. Lewis Publ., Boca Raton, Fla. pp. 201-211.

McGonigle, T.P., Miller, M.H., Evans, D.G., Fairchild, G.L., and Swan, J.A. 1990. A new method which gives an objective measure of colonization of roots by vesicular-arbuscular mycorrhizal fungi. New Phytol. 115: 495-501.

McHugh, J.M., and Dighton, J. 2004. Influence of mycorrhizal inoculation, inundation period, salinity, and phosphorus availability on the growth of two salt marsh grasses, Spartina alterniflora Lois., and Spartina cynosuroides (L.) Roth., in nursery systems. Restor. Ecol. 12: 533-545. doi: 10.1111/j. 1061-2971.2004.03109.x.

Miller, R.C., and Zedler, J.B. 2003. Responses of native and invasive wetland plants to hydroperiod and water depth. Plant Ecol. 167: 57-69. doi: 10.1023/A:1023918619073.

Muthukumar, T., Udaiyan, K., and Shanmughavel, P. 2004. Mycorrhiza in sedges - an overview. Mycorrhiza, 14: 65-77. doi: 10. 1007/s00572-004-0296-3. PMID: 14999550.

Newman, S., Grace, J.B., and Koebel, J.W. 1996. Effects of nutrients and hydroperiod on Typha, Cladium and Eleocharis: Implications for everglades restoration. Ecol. Appl. 6: 774-783.

Norris, J.R., Read, D.J., and Varma, A.K. 1994. Techniques for mycorrhizal research: methods in microbiology. Academic Press, San Diego, California.

Oliver, A.J., Smith, S.E., Nicholas, D.J.D., Wallace, W., and Smith, F.A. 1983. Activity of nitrate reductase in Trifolium subterraneum: effects of mycorrhizal infection and phosphate nutrition. New Phytol. 94: 63-79.

Poorter, H., and Nagel, O. 2000. The role of biomass allocation in the growth response of plants to different levels of light, $\mathrm{CO} 2$, nutrients and water: a quantitative review. Aust. J. Plant Phys. 27: 595-607.

Smith, S.E., and Read, D.J. 1997. Mycorrhizal symbiosis, 2nd ed. Academic Press, London, UK.

Smith, S.E., Nicholas, D.J.D., and Smith, F.A. 1979. The effect of early mycorrhizal infection on nodulation and nitrogen fixation in Trifolium subterraneum. Aust. J. Plant Phys. 6: 305-311.

SPSS. (1998). Systat 8.0 for Windows. Chicago, Ill..

Stevens, K.J., Spender, S.W., and Peterson, R.L. 2002. Phosphorus, arbuscular mycorrhizal fungi and performance of the wetland plant Lythrum salicaria L. under inundated conditions. Mycorrhiza, 12: 277-283. PMID: 12466914.

Technicon Industrial Systems 1974. Orthophosphate in water. Industrial method no. 94-70W. Technicon Industrial Systems, Tarrytown, N.Y.

Technicon Industrial Systems 1978. Nitrate and nitrite in water and wastewater. Industrial method No. 100-70W/B. Technicon Industrial Systems, Tarrytown, N.Y.

Tilman, D., and Wedin, D. 1991. Plant traits and resource reduction for five grasses growing on a nitrogen gradient. Ecology, 72: 685-700.

van der Valk, A.G. 1981. Succession in wetlands: a Gleasonian approach. Ecology, 62: 688-696.

Van Lierop, W. 1988. Determination of available phosphorus in acid and calcareous soils with the Kelowna multiple-element extractant. Soil Sci. 146: 284-291.

Wetzel, P.R., and van der Valk, A.G. 1998. Effects of nutrient and soil moisture on competition between Carex stricta, Phalaris arundinacea, and Typha latifolia. Plant Ecol. 138: 179-190. doi: 10.1023/A:1009751703827.

White, J.A., and Charvat, I. 1999. The mycorrhizal status of an emergent aquatic, Lythrum salicaria L., at different levels of phosphorus availability. Mycorrhiza, 9: 191-197. doi: 10.1007/ s005720050266. 